\title{
What Lies between the Public and the Secret?
}

\author{
Marian Rothstein
}

Is it appropriate to apply the simple dichotomy opposing public and private, transparently in use today, to the early modern period? Close examination of the evidence supports the notion that if, by and large, the public, can readily be identified in that world as in ours, the same understanding privacy in the earlymodern era is provided by conceiving of it as a relatively rare occurrence, and by reframing our understanding of the two opposing categories rather as public and secret, contrasting what is broadly known and what is closely held, protected, special information. The evidence in what follows, while drawn largely from nobles in sixteenth-century France, will be found to be broadly applicable to other parts of Europe. Privacy, in that it concerns that which was shielded from general view, is tricky to investigate; secrecy even more so. If something was public, it was there for all to see; if private, not so much; if secret, one might expect it to leave few traces. The question then is what kind of spaces, behaviours, and assumptions are shaped by each of these three categories.

\section{The Implications of Public}

The Dictionnaire du moyen français barely records the presence of public as a noun, the expression 'en public' being the exception. ${ }^{1}$ Adjectivally it means something that has official standing, that concerns everyone. Perhaps not so far from our modern suppositions, although usage raises questions. Not quite in the sense of public intellectuals today, high nobles, certainly, were public people. Jeanne d'Albret (1528-1572), queen regnant of Navarre, for example, explicitly declares herself to be a personne publique (public person) as she defends her decision during the wars of religion, in 1568 , to flee Béarn of which she was sovereign countess:

1 The entry for public in Huguet E., Dictionnaire de la langue française du siezième siècle, 7 vols. (Geneva: 2010 [Paris: 1925-1967]) seconds that of the Dictionnaire du moyen français, which, although it focuses on the French language $1330-1500$ is a useful modern instrument, readily consulted on the site of the Centre National de resources textuelles et lexicales, http://atilf .atilf.fr/. 
$[\mathrm{M}]$ es enfans et moy estions personnes publiques, et qu'il ne nous failloit ainsi hazarder; [...] et d'un costé me peignoyent si au vif l'affliction d'un peuple affligé loin de secours de sa dame souveraine, de l'autre la conscience, que (il faut que je confesse mon infirmité), ceux-là m'ont faict entrer la pitié au coeur, esmeue par cest amour naturelle que je doy à mes subjects. ${ }^{2}$

My children and I were public persons, and we were obliged not to put ourselves in such danger [...] On the one hand, they told me so vividly of the suffering of my people far from the support of their sovereign lady, on the other hand (and here I must confess my weakness) that awareness evoked pity in my heart, from that natural love I owe my subjects.

The queen declares that in her flight, she was motivated not by fear, but by a sense of public duty to preserve her power and thereby to protect all those subject to it. Kantorowicz's familiar distinction between the king's two bodies is in keeping with public as Jeanne uses it: the monarch had a (public) body politic, an immortal instantiation of the dignity of prince, at the same that time she or he had a mortal body natural. ${ }^{3}$ Only the latter retained access to the private, limited by the higher responsibilities of the public body politic. The passage quoted above shows that Jeanne, as queen regnant, was keenly aware of this distinction. Evoking it as she does could only be effective if she could equally count on her readers to be conscious of it.

Another case in point is that of King Henry II (1519-1559), who, at the time of his marriage in 1533, was second in line to the throne. Not unreasonably, his marriage contract declared that he and his spouse had communal goods. When he became king in 1547 this was no longer possible: he was now a fully public person. The state, deathless France, was effectively his spouse. ${ }^{4}$ Other provisions applied to the goods of his mortal wife, the queen, Catherine de' Medici (1519-1589). ${ }^{5}$ In fact, the monarchy, in part because it was so obviously

2 Albret J. d', Mémoires et poésie, ed. A. de Ruble (Paris: 1970 [Paris: 1893]) 87. http://gallica.bnf .fr/ark:/12148/bpt6k4467k/f3.image.r=memoires\%2oet\%2opoesies\%2ode\%2oJeanne\%2O d'albret. Translations are mine.

3 Kantorowicz E.H., The King's Two Bodies: A Study in Medieval Political Theology (Princeton, NJ: 2016 [Princeton: 1957]).

4 Rothstein M., The Androgyne in Early Modern France: Contextualizing the Power of Gender (New York: 2015), chapter 6, especially 135-136 and 112-119 on Queen Anne.

5 Cosandey F., La Reine de France, Symbole et Pouvoir (Paris: 200o) 86. She cites Jean Du Tillet Mémoires et recherches (Rouan, Philippe de Tours: 1578) 'la bource du roy est celle du peuple, non particulier au roy ni a la royne' ('the king's purse is that of the people, not the private possession of the king or the queen'), and Réne Chopin Trois livres du domaine de 
a family undertaking, provided the model of a macrocosm, mirrored by the microcosm of personal estates understood by analogy in the same terms, with the same public responsibilities. Well-managed family estates offered promise of a well-managed nation. Francis de La Noue's Discours politiques et militaires explicitly speaks of the domestic realm as 'an apprenticeship' for public matters. ${ }^{6}$ In this context, domestic turns out not to belong to the realm of the private, as modern usage would suggest; more often it considers family holdings as a basic unit of political economy, and in this sense, inherently building blocks of the public.

The family connections of Jeanne's mother, Marguerite de Navarre (14921549), queen consort of Navarre and sister of King Francis I (1494-1547), meant that she was often charged with official duties which she performed skilfully. Her role as a public person began when her brother became dauphin and she and her mother were included in the 'Valois trinity', images presenting Francis, Marguerite, and their mother, Louise de Savoy (1476-1531), joined as a single body politic with a single will and a single heart. ${ }^{7}$ The image was politically potent, strengthening Louise's hand as regent while Francis was imprisoned in Spain $\left(15^{25}-26\right)$, and reinforcing Marguerite's position as she negotiated with the emperor for her brother's release. It subsumed three individuals into what was intended to be received as a single public person.

\section{What Remains for the Private?}

The foregoing considerations of the implications of public set the lexical field implied by private in a different light. In antiquity, the dichotomy publicprivate tended to contrast political concerns of state with more generally

la Couronne de France (Paris, Michel Sonnius: 1613) 408. The King 'estant obligé de le [unclear antecedent] rendre à l'Estat, comme à son espouse toute entiere solide et sans aucune diminution' ('being obliged to render it to the State, as to his spouse, in its entirety without any diminution').

6 Noue François de La, Discours politiques et militaires du seigneur de La Noue, ed. F.E. Sutcliffe (Geneva: 1967) 62: 'Avant de traiter de la publique, je veux parler un peu de la domestique qui est comme un apprentissage et un degré pour parvenir à l'autre.' ‘[L] es gens de bien ont tant de contentement de voir l'union entretenuë, soit en une famille, ou en une cite' ('respectable people take pleasure in seeing unity preserved whether it be in a family or in a city') ibidem, 63. See also Hoffmann G., Montaigne's Career (Oxford: 1998) esp. 29-33 where the parallel is to Montaigne's estate and France. Such parallels were inherited from the Ancients starting with Aristotle and Xenophon.

7 See Lecoq A.-M., François Ier imaginaire. Symbolique et politique à l'aube de la Renaissance française (Paris: 1987), chapter 11, "L'un des angles du 'parfait triangle" esp. 393-397. 
social, convivial ones. ${ }^{8}$ The limits of privé are more difficult to draw based on sixteenth-century usage; examples quickly take us to a world we have lost. ${ }^{9}$ By private life we today understand individuals' domestic and non-professional arrangements including their families and their domestic space. This is not easy to apply to early modern nobles whose family business was running the county, the duchy, or the country. Political and dynastic concerns, not private preferences, shaped marriage arrangements. Job One for married noblewomen was to produce an heir, if they were queens of France, a male heir. Capable wives, like Marguerite, were often called upon to carry out their husbands' public, administrative tasks when the men were away on other business, usually fighting wars. These women might also be the chief administrative officer of a region in their own right, as Marguerite was of the duchies of Angouleme and of Berry. Infant princesses were betrothed at the age of two or three, allowing them to be raised in the country of their prospective husbands, better preparing them for the public tasks of their adult lives. Children were game pieces in the family business, assuring the continued prosperity of the kingdom or of their paternal house. Margaret of Austria (1480-1530) and Mary Stuart (15421587) come to mind as unhappy examples of toddlers who were sent to the French court with such expectations only to spend their adult lives elsewhere. All this is common knowledge, but so different from current conventions that it is worth pausing over to consider how many of the most private of modern decisions - whom to marry, how and where children are to be raised were public matters of state for nobles in another age. This is perhaps further complicated in French where privé and particulier are often used as simple

8 See for example Delignon B. - Dauvois N. - Cottegnies L. (eds.), L'Invention de la vie privée et le modèle d'Horace (Paris: 2017), especially Auger C., "Privatus chez Horace et dans sa première réception", in ibidem 91-108, who remarks (94) that the primary sense of privatus was negative: that which was not political or public. He elaborates (104), that Romans seem never to have been alone, suggesting little appetite for privacy as we understand it. Galland P., "Jean Salmon Macrin, peintre de sa vie privée", in ibidem 109-123, makes a similar argument by contrasting the French Neo-Latin poet Salmon Macrin's domestic, marital sense of private to Horace's non-political one.

9 Huguet, Dictionnaire de la langue française, vol. 6, entry privé, gives examples. From Amyot's translation of Plutarch (Vie d'Alexandre): 'Il luy fut aussi apporté un petit coffret [...] et il demanda à ses privez qui estoyent autour de luy quelle chose leur sembloit plus digne d'estre mise dedans' ('He was also brought a small case [...] and he asked those whom he trusted who were close to him what seemed to them most worthy of being put in it'). The sense here would be his most trusted associates. The same can be gleaned from several other quotations in this lemma. In the Dictionnaire du moyen français 'privé' is often presented in opposition to foreign, not to public. The public-private opposition appears by the mid-seventeenth century, attested by the Dictionnaire de l'Académie Française, which now also recognises a pejoritive, trop privé for someone who does not respect social distance. 
synonyms, setting the individual against a group, a private residence, maison particulière, against one occupied by, say, a business. ${ }^{10}$ In the period that concerns this essay, businesses were in any case often housed in their owners' residences: nobles ruled from their châteaux, printers tended to live over and in their shops, bakers in theirs. This conflation of functions further undermined the possibilities of giving a distinct status to the private.

Similarly, household domesticity cannot be taken as a synonym for privacy. A careful reading of the tales in Marguerite de Navarre's Heptameron quickly makes it clear that this was true throughout society. Certainly, life in a royal château was anything but private. The Habsburg princess Eleanor (1498-1558) became queen of France in 153 o when she arrived with twelve Spanish ladies in waiting, who accompanied her day and night. Three years later she had thirty-four ladies. ${ }^{11}$ By mid-century, the household of the queen of France numbered in the hundreds. ${ }^{12}$ The size of the royal household made space an issue for the itinerant court. Physical evidence of royal abodes suggests how little private space the queen or her ladies in waiting might expect. This was equally the case for others following the court.

\section{$3 \quad$ Lodging Royalty}

The historian Lucien Febvre suggested long ago that, at a minimum, domestic privacy requires hallways. Hallways make bedrooms private by eliminating the need to pass through them to get to another part of the dwelling. While hallways exist in sixteenth century châteaux, they are generally limited to the wings that housed less important members of the court. The layout of the logis, the suite of rooms intended for the owners of a great châteaux in the sixteenth century, suggests that privacy was not a priority and indeed perhaps not even a consideration for either their architects or their inhabitants. Over the years, as the suite of rooms preceding the king's bedchamber grew, each room came to have a filtering function, making the king less readily accessible to outsiders, or even to the court as a whole. The general practice, starting in the reign of Henry II (r. 1547-1559), was that the king's quarters be tri-partite: salle,

\footnotetext{
10 See Duby G. - Ariès Ph. - Chartier R. (eds.), Histoire de la vie privée, vol. 3 (Paris: 1986).

11 Rentet T., Anne de Montmorency, Grand maître de François I (Rennes: 2011) 249.

12 Kolk C. zum, "L'Evolution du mécénat de Catherine de Medici d'après sa correspondance depuis son arrivée en France jusqu'à la mort de Charles IX", in S. Frommel - G. Wolf (eds.), Il mecenatismo di Caterina de'Medici: Poesi, feste, musica, pittura, scultura, architettura (Venice: 2008) 63-87, here 65. See also Akkerman N. (ed.), The Politics of Female Households: Ladies-in-Waiting across Early Modern Europe (Leiden: 2014).
} 
ante-chambre, chambre. Earlier, there was only a salle preceding the chambre, offering the king even less protection from the general public received there. All parts of the king's logis remained places where the king conducted business and all were places where the king was not alone. The chambre, the most intimate of the three, was generally about ten meters on each side.

The queen had no more privacy than did the king. Her bedchamber was nearly as spacious and had, like most chambres in the donjon (the renovated original part of the château where the royal quarters were situated), an attached garderobe. This was not, as modern usage might lead one to might suppose, some kind of armoire or wardrobe; it was a true room, smaller than the chambre but generally with a window, intended for the chests containing clothing and other effects that moved with an itinerant court. It also held cots for some of the queen's unmarried ladies in waiting, placing them close by, should they be needed. There is no documentation of how many cots - presumably rather like sturdy folding camp beds - were included with the furnishings that travelled with the court. Permanent beds were for those assigned a chambre, generally placed next to the fire-place, surrounded by curtains, sometimes on a raised platform, sometimes partially surrounded by a railing to hold back the crowd of courtiers. The royal château of Saint-Germain-en Laye may serve as an example. Dating from the Middle Ages, heavily renovated in the $153 \mathrm{Os}$, it was a frequent residence of the French court, second only to Paris in the reign of Francis I (r. 1515-1547) and of Charles IX (r. 1560-1574), most frequented under Henry II. ${ }^{13}$ Rooms in the basse-cour, the expansive extension built on to the old central castle (the donjon), were reserved for important but not royal courtiers and were connected by a corridor. On the ground or first floor (terminology shifts), nobles' rooms in the donjon also open on to an exterior hallway. Although courtiers and others were in public view in such a passageway, it protected privacy within their chambre. The hallway disappears in the floor above where the royal suites are located.

In the logis of the king and of the queen, the only rooms that are not on the way to other rooms are the small cabinets built into nooks and towers. These often contain small circular stairs giving another avenue of access to the royal quarters and at the same time providing a way for the king, unobserved, to leave his logis for the gardens, the park, or the world beyond. Whether this was

13 See Chatenet M., La Cour de France au XVIe siècle: vie sociale et architecture (Paris: 2002) 318-323. Idem, "Une Demeure royale au milieu du seizième siècle. La distribution des espaces au château de Saint-Germain-en-Laye”, Revue de l'art 81 (1988) 20-30; see 25, 27 for the distribution of rooms in the basse-cour. See also Faisant É. (ed.), Henry II à Saint-Germain-en-Laye, une cour royal à la Renaissance (Paris: 2019). 
private or secret must have depended on individual circumstances. In addition to what carefully historically reconstructed ground plans make visible, contemporary texts explain that the king's premier gentilhomme de la chambre (first gentleman of the chamber), an office and honour conferred upon such favourites as the maréchal de St-André or Albert de Gondi, duke of Retz, had the right to a bed at the foot of the king's, as well as to a logis of his own. The size of the king's bedchamber in Saint-Germain was about $100 \mathrm{~m}^{2}$ allowing space for several cots in addition to the king's bed. In the absence of the premier gentilhomme, the king could offer that bed to someone else. Valets de chambre might have cots in the adjoining garderobe. The ambassador from Ferrara, Alverotti, noted disapprovingly that Henry II sometimes chose to share his own bed, often with the constable (chief military officer), Anne de Montmorency. ${ }^{14}$ In Saint Germain, the separate, personal logis of the premier gentilhomme also communicated directly, now vertically, with the garderobe next to the king's chambre above, via an interior staircase. In the Louvre, that was true for Montmorency, who paid for the construction of stairs giving him direct access to the king's quarters. ${ }^{15}$ The king's best hope of a space to which he could control access was in the smaller rooms attached to his chambre, primarily a cabinet and perhaps the garderobe. As regent, Catherine de' Medici's instructions concerning the conditions of the Prince de Condés imprisonment in 1562 imply this division of space: the prisoner is not to be left alone in his chambre, but his garderobe is to be respected as a private space, one which he may control.

Qu'il couschera en la chambre du Prince deux de ses Valletz de chambre ausquelz avec le reste de ses gens il pourra communiquer et parler en l'oreille; que ledict Prince poura aller en sa garde-robbe sans qu'aucuns desdictz gardes y entrent. ${ }^{16}$

Two of his valets de chambre are to sleep in the prince's chambre with whom he may speak or whisper, as with the rest of his entourage; the prince may enter his garderobe without being accompanied by any of the aforementioned guards.

\footnotetext{
14 Chatenet, La Cour de France au XVI e siècle 133.

15 Ibidem, 77-79.

16 Letter of Catherine de' Medici from Chartres, 3 Jan 1562 os, adding a postscript in her own hand describing the surveillance of Condé. Medici Catherine de', Lettres de Catherine de Médicis, ed. H. de la Ferrière, vol. 1 (Paris: 1880) 462.
} 
Such spaces would have been available for conversations conducted in secret and unexceptionally, at Saint Germain, many have not been preserved. Galleries, where they existed, also seem to have been treated as the king's preserve. ${ }^{17}$ At Fontainebleau, where the galerie is famous for its decoration, it was connected both to the salle and the chambre of the king.

As in most royal châteaux, the two royal suites in Saint Germain communicated directly with one another. ${ }^{18}$ The queen's chambre was the one place where the king might expect to control access, his own and others' - although the queen's ladies remained, if perhaps only in the garderobe. The architecture bespeaks a society that had little need for the kind of basic privacy we might consider essential. The queen's chambre could however be used to provide the king the possibility of secrecy, as when in ${ }^{155^{1}}$ Henry II wished to speak to François de Scépeaux, sire de Vieilleville (1509-1571) without the knowledge of other courtiers. ${ }^{19}$ The master of the king's wardrobe instructed Vieilleville to knock on the door of the queen's chamber in the evening, something unthinkable without such an invitation. Their meeting was presumably conducted unobserved. Before dinner, however, the queen's chamber was as much a public place as the king's; like him, she too was constantly attended, from the time of her lever, as she dressed, and not only by women. Alvarotti, the ambassador from Ferrara, wrote to Modena that he had heard that Francis I, coming to the baths on the ground floor of Fontainebleau on 18 June 1540, accompanied by the Constable, the Cardinal of Lorraine, and Hippolito d'Este, chatted with Mme d'Etampes, Mme Marguerite, and Mme de Rothelin naked in the waters. ${ }^{20}$

The royal château at Villers-Cotterets, another frequent stop for the court, similarly had about 40 rooms for guests who were not direct members of the royal family. Located in the basse-cour were nearly 100 meters of corridors in the newly added section of the château. ${ }^{21}$ Once again, the logis of the king and queen are in the recently remodelled original part of the building. The queen's bedroom allows access to the smaller rooms in her suite and directly to the

\footnotetext{
17 Taking the term in its modern sense. In sixteenth-century usage 'galerie' designates such large, long, narrow, often elaborately decorated spaces but also hallways, corridors, balconies, and raised walkways.

18 Chatenet, La Cour de France au XVI e siècle 142.

19 Ibidem, 194.

$20 \quad$ Ibidem, $168-71$.

21 Ibidem, 83-93. Construction of the basse-cour started early in the 1530s, was ready by 1539 .
} 
king's antechamber. Several small staircases in this wing also allow direct entry from the royal logis to the palace gardens. ${ }^{22}$

The construction of the 'new' section of the Louvre, now the oldest remaining section, the Cour carré, tells much the same story. Here the logis of the king and queen were joined via their cabinets. Privacy might have meant situations in which one was, or hoped to remain, in control of the people to whom one might be visible or audible, but the ground plans of châteaux suggest the degree to which such control was hard to come by and hard to maintain.

\section{4}

\section{Verbal Evidence}

Textual evidence seconds what architecture suggests. Marguerite de Navarre's poem, Les Prisons describes the creation of a private place for her mother, Louise de Savoy, on her deathbed - made by drawing the bed curtains. Louise de Savoie: '[...] seule en son lict estant, / Ce que a ouy qui l'aloit escoutant, / Parloit à Dieu comme espouse à espoux' (1. 2530). ('being alone in her bed / As was heard by the listener / She spoke to God as spouse to her husband') (1. 2337-39). ${ }^{23}$ Small privacy accorded a princess.

Sometimes bed curtains seem not to have done the trick; intimacy too may need to be redefined or questioned. We are told that Francis I observed the wedding night of the first of his sons to marry, the future Henry II. ${ }^{24}$ Then the bride's uncle, Pope Clement VII (1478-1534), stopped by the couple's bedroom in the morning, while they were still in bed. Our understanding of the several the sexually explicit anecdotes concerning the infancy and childhood of Louis XIII (1601-1643) recounted by Jean Héroard (the dauphin's appointed physician), in his Journal, might be received differently when read in the light of a more historical sense of what was normal in the early seventeenth century. ${ }^{25}$ After close examination of many ground plans of Renaissance châteaux, Monique Chatenet, the architectural historian from whom I have drawn much of my knowledge of royal residences, is brought to wonder:

22 See Villers-Cotterets, http://aisne.media.tourinsoft.com/upload/Telechargez-la-brochure -Le-Chateau-de-Villers-Cotterets.pdf.

23 Navarre Marguerite de, Les Prisons, ed. S. Glasson (Geneva: 1978).

24 Knecht R.J., Renaissance Prince and Warrior (Cambridge: 1994) 300. The passage continues: "Next morning, Clement found the young couple still in bed and noted with pleasure their satisfied looks".

25 Héroard Jean, Journal de Jean Héroard, médecin de Louis XIII, ed. M. Foisil, 2 vols. (Paris: 1989). 
que signifie 'privé' à une époque où toute personne de qualité vit entourée d'une nuée de familiers, dans une société dont la faveur, c'est à dire le passe-droit, est la pierre angulaire $[\ldots]{ }^{26}$

what 'private' might mean at a time where nobles lived surrounded by a swarm of domestics and followers, a society where the keystone was favour, that is, the freedom to approach.

Architectural evidence cannot tell us much about other social classes since few more modest houses have survived sufficiently intact to speak to questions of privacy. In other forthcoming work I expand the focus of my investigation of the nature of privacy (including its absence or violation) to other social classes where the evidence tends to be primarily textual, gleaned from the many tales, nouvelles, of the period, especially Marguerite de Navarre's Heptameron, involving beds shared among travellers, invaded by masters, servants, or neighbours. Speaking in generalities for the moment, apprentices slept under a bench in the shop; with some luck, they would take up their private lives later. Peasant houses often had only a single room in which the family slept, the same space where all the activities of daily life took place unless there was a sleeping loft, in which, again, everyone slept. Historically contextualised, all these facts converge to undermine the application of privacy in the modern sense to the world we are examining, and consequently to call for its reconsideration.

The Public, the Private, and the Secret in Early-Modern Correspondence

If, as the evidence presented above tends to argue, the twenty-first century understanding of privacy has only limited application in the sixteenth century, this puts new pressures on our third category, the secret: that which is to be divulged only to a select few, and to be kept from all others. We have seen a glimmer of it in the king's manoeuvre, inviting Vieilleville to knock on the queen's door. Written correspondence can be a useful reference point as it operated in all three modes, the public, as in royal edicts, decrees, or notifications addressed to the general public; the private, as in letters inquiring after an addressee's health, family, or sharing news of mutual interest; and the secret, as in diplomatic correspondence. Letters give us authentic access to interpersonal relationships among contemporaries, preserving the words and thoughts

26 Chatenet, La Cour de France au XVI ${ }^{e}$ siècle 52. 
of primary actors interacting among themselves, allowing us to see how they configured their relationships. As Juan Luis Vives put it: 'epistola est sermo absentium per litteras' ('a letter is a conversation by means of written words between people not in each other's presence'). ${ }^{27}$

Letters are generally addressed to a specific person, inviting the assumption that correspondence between two people who know each other well might generally be private, that is, limited to the writer and the addressee. This was rarely the case. In fact, such letters often include overt references to the expectation that they might well be read aloud to people in the recipient's circle or passed on to others who might be interested. ${ }^{28}$ So we find the Cardinal Jean Du Bellay (1492-156o) writing to Anne de Montmorency (1493-1567), when he was Grand Master of France: 'Quant voz lectres pour elle [Marguerite de Navarre] tombent en mes mains, je ne les guarde guerre'.29 ('When your letters for Marguerite de Navarre fall into my hands, I do not keep them long'). Or: 'Monseigneur, incontinent que j'ay receu vostre lectre du 6 e, je l'ay portee à la royne de Navarre qui y a beaucoup plus prins de plaisir que de déplaisir'. ${ }^{30}$ ('My lord, as soon as I received your letter I took it to the queen of Navarre who took more pleasure than displeasure from it'). Letters are filled with what might seem to be trivial reports of good health, minor illnesses, as well as more serious ones. Given the dynastic and policy implications of the birth or death of nobles, given how quickly minor illnesses might turn intractably deadly, this can be understood as news of general, public importance. ${ }^{31}$

Much of Marguerite de Navarre's correspondence has been preserved and published. As a matter of protocol, no secretary wrote the letters from Marguerite to her brother, they were written entirely in her hand. Still, she

27 Fantazzi Ch. (ed.), De conscribendis epistolis (Leiden: 1989) 22.

28 Daybell J., The Material Letter (New York: 2012) 18. See also Lestringant F. (ed.), L'Epistolaire au XVI ${ }^{e}$ siècle (Paris: 2001) where Catherine C. Mangien in her "Conclusion" (237-244) to this volume, 240, cites Pasquier writing to Eduard Molé after he had seen the letter Molé wrote to someone else, evidence that in an age of limited sources of information, letters were shared among people with social ties, here, among robins.

29 Letter 499, Du Bellay to Montmorency, 7 July 1537, in Du Bellay J., Correspondance du Cardinal Jean Du Bellay, ed. R. Scheurer - L. Petris et al., vol. 3 (1537-1547) (Paris: 2008) 51.

$30 \quad$ Ibidem, 52 , letter dated 10 July 1537.

31 Other seemingly personal, private, letters were in fact received by a trusted secretary, or even sent from secretary to secretary, as seems to have the case for the correspondence between Marguerite and her husband, explaining why almost none of her many surviving letters were addressed to him. Rentet, Anne de Montmorency 29, responding to the observation of Pierre Jourda in his biography of Marguerite. Montmorency too relied on his secretary, Nicolas Berthereau, to conduct the bulk of his correspondence. 
never forgets his public status. ${ }^{32} \mathrm{He}$ is always addressed as Monseigneur (lesser nobles and commoners would address the king as sire). ${ }^{33}$ Mixing the political and the private, they end with some close variant of 'your humble and obedient subject and sister, Marguerite. Their contents were protected from prying eyes by the courier (whence the modern French for mail, courier); the envelope had yet to be invented. The addressee was indicated on the verso of the folded document: to the King my sovereign lord. Seals were attached to official letters, not to close them but to denote the status of the writer. Still today, in modern French, the verb to seal, sceller, has as its first meaning to affix an authenticating mark to something rather than to close it.

In diplomatic correspondence, it was often essential to limit access to the information conveyed, to protect secrecy. ${ }^{34}$ Such letters, like those from Jean Du Bellay to the king, often alternated passages written in normal script with encoded passages, clearly demarking the public and the secret parts of a letter. The use of ciphers is a familiar means of preserving secrecy. My concern here is primarily with some other means of concealment that may be less familiar. Letters containing sensitive information, including those between the king's sister and the monarch, were generally transmitted by a trusted courier known to both sides. The bearer himself was likely to be noble. Unlike Du Bellay, Marguerite does not seem to have protected the politically sensitive contents of her letters by any using ciphers or invisible ink. However, she frequently had recourse to another common method for assuring the secrecy of political correspondence, what was termed a lettre vive (living letter) wherein the written missive (holograph) was limited to a declaration that the bearer was authorised and competent to convey the essential message which was to be conveyed orally. She does this quite regularly when conveying diplomatic matters to the king: 'Ce porteur vous en dira la vérité de tout; qui me gardera de

32 In the king's own verse epistles, he addresses his sister in the familiar $t u$, a form he never uses to his mother. See Ep. 2 and 4 in François I, Oeuvres poétiques, ed. J.E. Kane (Geneva: 1984) 296-297, 303-304.

33 See Du Bellay, Correspondance du Cardinal Jean Du Bellay. The king and his family might address high nobles as mon cousin, or more rarely mon neveu, etc.; the response to them was generally addressed to monseigneur or if to a woman, madame.

34 Writing in ciphers is well known from at least the fifteenth century as is writing in various kinds of 'invisible' ink (artichoke, lemon juice). Modern research has drawn attention to other available physical methods of rendering a letter tamper-proof. See The Dictionary of Letterlocking (2015). Online edition, http://letterlocking.org/dictionary (2015), or https:// www.youtube.com/watch?v=dzPEıMCgXxo, an example modeled on Mary Stuart's last letter to King Henry III of France. 
vous en faire redite'35 ('The bearer will tell you the entire truth, which spares me having to recount it to you').

The correspondence of Henry II is also filled with such missives, like this one to Montmorency while the constable was held prisoner by the emperor (1o August 1557-October 1558):

Mon amy le porteur vous dyra les resons pour quoy je le vous anvoye et ausy qui massamble que par une lestre je ne vous sares sy byen fayre antandre mon intansyon coume il fera de vive voix quy me gardera vous faire plus longue lestre sy n est de vous prier de croyre que vous maves an porte tout lese e le contantemant que je saves james avoyr et nespere point le recouver que je ne vous voye du tout an lyberte quy ne sera james sy tost que le desyre vostre bon et parfait ami HENRY. ${ }^{36}$

My friend, the bearer will tell you why I am sending you this letter and also why it seemed to me that by a letter I could not explain my aims to you as well as he will do by speaking, which spares me writing further except to beg that you believe that you have given me all the ease and contentment that I know I will never have hope to recover until I see you entirely at liberty, which will never be so soon as desired by your good and total friend, HENRY.

Catherine de' Medici's correspondence also contains such lettres vives, of which the first may have been written to Montmorency on 5 December 1560, the very day of the death of Francis II (1544-156o), that is, the day she took over the power of the sovereign.

Mon cousin, j'ay choisy le s[ieu]r de Lanssac, chevalier de l'ordre, présent porteur, comme personnaige auquel je me fye grandement et sçay aussi que vous croyrez bien voluntiers, pour envoier devers vous vous dire et faire entendre aucune choses de ma part; à quoy je vous prie adjouster autant de foy que vous ferez à moi mesmes. ${ }^{37}$

Navarre Marguerite de, Nouvelles Lettres de la Reine de Navarre adressées au roi François I ${ }^{e r}$, son Frère, ed. F. Genin (New York: 1965 [Paris: 1842]) 186.

36 'Lettre 11' in Gail J.-B. (ed.), Lettres inédites de Henry II, Diane de Poitiers, Marie Stuart, François, dauphin, etc, adressées au connétable Anne de Montmorency, ou Correspondance secrète de la cour sous Henri II (Paris: 1828) 40.

37 Medici Catherine de', Lettres de Catherine de Médicis, ed. H. de la Ferrière, vol. 1 (Paris: 1880) 155. The spelling makes clear that exceptionally, this letter was not a holograph. 
My cousin, I have selected the lord of Lansac, knight of the order [of Saint Michel], who brings you this as a person in whom I have great confidence and whom I know that you will readily believe, to send to you to tell you and explain several things, whom I beg you to trust as you would myself.

This may be the shortest example of a lettre vive from the queen-mother; Catherine was a prodigious letter writer. ${ }^{38}$ Most of her letters declaring that their secret contents are confided to oral transmission also include in written form some anodyne news. The strength of the lettre vive is that the living code could not be broken and indeed could easily be falsified by the bearer if captured; and if the recipient was not in the expected location, the bearer would feel himself honour-bound to continue until the message had reached its intended recipient. In all events, secrecy would be maintained.

\section{In Conclusion}

Public, private, and secret demonstrably had different ranges than modern customs would suggest. Among high nobles in sixteenth-century France, the lack of focus on privacy in our modern sense is salient in the physical arrangements of the living quarters of the most powerful people in the realm. This bespeaks how far the domain of the public extended, and how little our need for personal privacy was current in the past. For most people, arguably peasants as well as the elite, being alone was an exceptional state, as it seems to have been for elites among the Ancients. While there may be a special case to be made for personnes publiques, other aspects of my research into this question support the idea that it was broadly true for society at large. The realm of the private, while it certainly existed, was narrow. Intimacy, in all its senses, surely existed, but its boundaries are difficult to trace exactly: they blend, often unexpectedly, on one end into the public, and often unremarked on the other, into the consciously protected secret.

38 On Catherine's letter writing see Gellard M., Une Reine épistolaire: lettres et pouvoir au temps de Catherine de Médicis (Paris: 2014). 


\section{Selective Bibliography}

Albret J. d', Mémoires et poésie, ed. A. de Ruble (Paris: 1970 [Paris: 1893]).

Chatenet M., La Cour de France au XVI e siècle: vie sociale et architecture (Paris: 2002).

Cosandey F., La Reine de France, Symbole et Pouvoir (Paris: 200o).

Daybell J., The Material Letter (New York: 2012).

Delignon B. - Dauvois N. - Cottegnies L. (eds.), L'Invention de la vie privée et le modèle d'Horace (Paris: 2017).

Du Bellay J., Correspondance du Cardinal Jean Du Bellay, ed. R. Scheurer - L. Petris et al., 7 vols. (Paris: 2008).

Duby G. - Ariès Ph. - Chartier R. (eds.), Histoire de la vie privée, vol. 3 (Paris: 1986).

Faisant É. (ed.), Henry II à Saint-Germain-en-Laye, une cour royal à la Renaissance (Paris: 2019).

Gail J.-B. (ed.), Lettres inédites de Henry II, Diane de Poitiers, Marie Stuart, François, dauphin, etc, adressées au connétable Anne de Montmorency, ou Correspondance secrète de la cour sous Henri II (Paris: 1828).

Gellard M., Une Reine épistolaire: lettres et pouvoir au temps de Catherine de Médicis (Paris: 2014).

Héroard Jean, Journal de Jean Héroard, médecin de Louis XIII, ed. M. Foisil, 2 vols. (Paris: 1989).

Hoffmann G., Montaigne's Career (Oxford: 1998).

Kantorowicz E.H., The King's Two Bodies: A Study in Medieval Political Theology (Princeton, NJ: 2016 [Princeton: 1957]).

Knecht R.J., Renaissance Prince and Warrior (Cambridge: 1994).

Kolk C. zum, "L'Evolution du mécénat de Catherine de Medici d'après sa correspondance depuis son arrivée en France jusqu'à la mort de Charles IX", in S. Frommel G. Wolf (eds.), Il mecenatismo di Caterina de'Medici: Poesi, feste, musica, pittura, scultura, architettura (Venice: 2008) 63-87.

Lecoq A.-M., François I ${ }^{\text {er }}$ imaginaire. Symbolique et politique à l'aube de la Renaissance française (Paris: 1987).

Lestringant F. (ed.), L'Epistolaire au XVI'e siècle (Paris: 2001).

Medici Catherine de', Lettres de Catherine de Médicis, ed. H. de la Ferrière, 11 vols. (Paris: 1880-1943).

Navarre Marguerite de, Nouvelles Lettres de la Reine de Navarre adressées au roi François $I^{e r}$, son Frère, ed. F. Genin (New York: 1965 [Paris: 1842]).

Noue François de La, Discours politiques et militaires du seigneur de La Noue, ed. F.E. Sutcliffe (Geneva: 1967).

Rentet T., Anne de Montmorency, Grand maître de François I (Rennes: 2011).

Rothstein M., The Androgyne in Early Modern France: Contextualizing the Power of Gender (New York: 2015). 